\title{
A városnövekedés területi eltérései Európában, különös tekintettel a járműipari városokra
}

\section{Spatial disparities of urban growth in Europe with special regard to locations of automotive industry}

\author{
HARDI TAMÁS, BARÁTH GABRIELLA, CSIZMADIA ZOLTÁN, \\ USZKAI ANDREA
}

\begin{abstract}
HARDI Tamás: tudományos főmunkatárs, MTA Közgazdaság- és Regionális-Tudományi Kutatóközpont, Regionális Kutatások Intézete, Győr; egyetemi docens, Széchenyi István Egyetem, Regionális Tudományi és Közpolitikai Tanszék, Győr; hardit@rkk.hu

BARÁTH Gabriella: tudományos munkatárs, Kodolányi János Főiskola, Szociális Tanulmányok Tanszék, Székesfehérvár, gbarath@kodolanyi.hu

CSIZMADIA Zoltán: egyetemi docens, Széchenyi István Egyetem, Szociális Munka Tanszék, Győr; tudományos munkatárs, MTA Közgazdaság- és Regionális Tudományi Kutatóközpont, Regionális Kutatások Intézete, Győr; cszoltan@rkk.hu

USZKAI Andrea: PhD-hallgató, Széchenyi István Egyetem, Regionális- és Gazdaságtudományi Doktori Iskola, Győr; ügyvivő szakértő, MTA Közgazdaság- és Regionális Tudományi Kutatóközpont, Regionális Kutatások Intézete, Győr; auszkai@rkk.hu
\end{abstract}

KULCSSZAVAK: urbanizáció, városnövekedés, jármüipar

ABSZTRAKT: Az európai városfejlődési folyamatok időbeli szakaszolása mellett rá szeretnénk világítani annak térbeli eltéréseire is. A 21. század első évtizedében a migráció szinte soha nem látott helyzete következett be a kontinensen, mivel a határok korlátozó szerepe nagymértékben csökkent, a közlekedési lehetőségek javulásával az európai nemzetállami mozaik egyes elemeinek elszigeteltsége oldódott, nemcsak az uniós tagállamok számára, hanem a tagsággal nem rendelkezők számára is. Tanulmányunk bemutatja, hogy az egész kontinensre jellemző vándorlási folyamatok eltéro” városfejlődési tendenciákat gerjesztenek az egyes nagyrégiókban. Önálló elemzésekben közelítjük meg a városfejlődés területi eltéréseit. Először az általános urbanizációs tendenciákat vizsgáljuk az egyes államokban, majd a nagyvárosok fejlődési jellegzetességeit mutatjuk be. Ezután a középvárosok szélesebb adatbázison nyugvó elemzése következik, végül egy olyan városkör elemzését végezzük el, amelyek jármüipari telephellyel rendelkeznek.

A tanulmány négy fő gondolati egységre tagolható. Elsőként a kontinens demográfiai változásait és urbanizációs folyamatait tekintjük át. Ezt követően a nagyvárosokra fókuszálunk, majd az 50-500 ezer fő közötti méretkategóriára. Az utolsó alfejezet pedig az európai járműipari várostérségek jellemzőit foglalja össze, népességszámtól függetlenül. Ezen elemzés célja feltárni, hogy a járműipari ágazat milyen hatással van az adott várostérség társadalmi-gazdasági mutatóira. Feltételezésünk szerint az ágazat pozitívan befolyásolja az adott térség gazdasági teljesítményét és hatással lehet annak demográfiai folyamataira is. Fontos kutatási

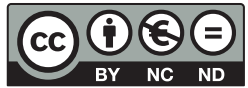


kérdés, hogy napjainkban melyek a járműgyártás által kedvelt európai országok, nagyrégiók, települési méretkategóriák. Törekszünk Győr városát pozicionálni e speciális városkörön belül.

Nyilván az elemzések jellege és adatigénye eltérő földrajzi kiterjedést és városnagyság szerinti lehatárolást igényel, de a következtetéseinket együttesen alátámasztják: kimutatják azokat a tipikus városfejlődési zónákat Európában, amelyek hasonló jellegzetességekkel írhatók le. Bizonyítják, hogy napjainkban a városfejlődési szakaszok nem egységesen jelennek meg a kontinensen, s valószínűsíthető, a továbbfejlődés sem a klasszikus szakaszok szerint fog végbemenni, hanem sokkal inkább egy centrum-periféria viszonyrendszer látszik kibontakozni, s a nagyvárosok fejlődésének kizárólagossága is csak a kontinens bizonyos államaiban érvényesül.

Tamás HARDI: senior research fellow, Institute for Regional Studies, Research Centre for Economic and Regional Studies, Hungarian Academy of Sciences, Györ; associate professor, Department of Regional Studies and Public Policy, Széchenyi István University, Győr; hardit@rkk.hu

Gabriella BARÁTH: research fellow, Department of Social Studies, Kodolányi János University of Applied Sciences, Székesfehérvár, gbarath@kodolanyi.hu

Zoltán CSIZMADIA: associate professor, Department of Social Studies, Széchenyi István University, Györ; research fellow, Institute for Regional Studies, Research Centre for Economic and Regional Studies, Hungarian Academy of Sciences, Györ; cszoltan@rkk.hu

Andrea USZKAI: PhD student, Doctoral School of Regional- and Economic Sciences, Széchenyi István University, Györ; executive expert, Institute for Regional Studies, Research Centre for Economic and Regional Studies, Hungarian Academy of Sciences, Győr; auszkai@rkk.hu

KEYWORDS: urbanization, urban sprawl, automotive industry

ABSTRACT: In addition to the separation of the phases of the European Union urban development processes, this paper seeks to trace their special disparities. By the 21st century Europe faced a special situation, practically never experienced before in its history as regards migration, by the breaking down of the blocking role of state borders and the improvement of transportation facilities. These factors led to the dissolution of the isolation of some elements in the European mosaic of nation states, and this was relevant not only for the European Union member states but also for countries that are not EU members. Our paper reveals how the pan-European migration processes induce a variety of urban development tendencies in the various macro-regions. Different independent analyses are provided to discuss the spatial disparities of urban development.

Firstly, general urban development tendencies are examined in the respective countries, and the development characteristics of large cities are introduced. This is followed by an analysis of medium-sized cities on the basis of a broad database, and finally the paper discusses the survey of a group of cities which host automotive companies. In other words, the paper is composed of four chapters. First of all, we review the demographic changes and the urbanization processes of the continent. After that, we focus on large cities, and then on the size category of 50 000-500 000 inhabitants. In the last chapter we discuss the features of European automotive settlements, regardless of the population. The aim of this analysis is to explore the impacts of automotive industry on the social and economic indicators of the examined urban areas. We assume this sector has got a positive impact on the economic performance of a given urban area, and it can have an impact on its demographic processes as well. An important research question is which European countries, great regions and settlement size categories are favoured by the automotive industry. In addition, we try to trace the position of Gyor in this special group of cities.

Evidently, the type and data demand of these analyses requires various geographical ranges and city size categories, but our conclusions are supported. Typical urban development 
zones are featured in Europe, and they may be described by similar characteristics, which proves that in our age the phases of urban development are not the same all over the continent. Further development will probably not follow the classical urban development phases, either. It is much more likely to have a centre-periphery relationship in the future, and the exclusivity of the development of large cities will only be experienced in some European countries.

The development of cities is not equal in Europe, and we can find variant processes in different great regions. In the past, the differences were connected to the economic development of single countries, nowadays changes are formed by globalization tendencies, the appreciation of dynamic metropolitan areas and migration processes.

The crisis in 2008 - which depressed the poorer areas more strongly - stimulated these processes. Today, the internal immigration and international emigration determine the development of areas in poorer countries. In contrast, we see the development of prospering urban regions in the developed parts of the continent, while other parts of the wealthy countries can be found in the phase of deurbanization. In other words, there could be a more balanced spatial development in these countries.

\section{Bevezetés}

Az urbanizáció folyamatát a földrajztudomány és a regionális tudomány a 20. század 60-as éveitől vizsgálja intenzíven. Az addig tapasztalható városnövekedés megtorpant, $\mathrm{s}$ a fejlett országokban megindult a városokból a környező területekre irányuló kiköltözés, a szuburbanizáció. Világossá vált, hogy a városfejlődés nem egyirányú, hanem szakaszos folyamat. Az európai urbanizációt holland szerzők bontották szakaszokra (Berg 1981). Az ő munkájukat gondolta tovább Enyedi György, kimutatta a globálisan érvényesülő szakaszokat és a közép-európai sajátosságokat, amelyeket elsősorban az urbanizációs folyamatok megkésettségében és kisebb intenzitásában foglalhatunk össze (Enyedi 1988). Az urbanizációs szakaszok hátterében elsősorban gazdasági összefüggések álltak, Enyedi a szakaszokat összekapcsolta pl. a Kondratyev-ciklusokkal, bár késői cikkeiben e véleményét módosította a legújabb folyamatok hatására: a városodás folyamatai illeszkednek a gazdasági ciklusokhoz, de a globalizációs tendenciák új hatásokat generálnak, s kiemelkedik a nagyvárosi térségek népességvonzó képessége (Enyedi 2012). A szakaszok Európában nem egységesen érvényesülnek, nem is feltétlenül követik egymást szabályosan, s ez elsősorban nem országonként, hanem a kontinens nagyrégiói szerint változik (Cheshire 1995; Chorianopoulos 2002). Különösen fontos globalizációs folyamat a határok átjárhatóságának növekedése, az utazás és a költözés lehetőségének elterjedése (legalábbis a világ népességének egy része számára). Így ma már a városfejlődési folyamatok nem a nemzetállamon belüli migráció eredményeként formálódnak, hanem egyre nagyobb arányban a nemzetközi migráció is látható hatást gyakorol rájuk. 


\section{A demográfiai változások és az urbanizáció összefüggései}

A gazdasági hatások mellett a városfejlődés fontos összetevői a demográfiai változások. Az elmúlt két évtizedben Európa fejlett országaiban az urbanizációra ható legfontosabb demográfiai folyamatok között meg kell említenünk a korábbi évtizedekhez képest alacsonyabb természetes lakosságszám-növekedést, a várható élettartam kitolódását (így a népesség korösszetételében az idősek arányának növekedését), a növekvő nemzetközi migrációs nyereséget, valamint az átalakuló belső migrációt. A házasságok számának csökkenése, az együttélés elterjedése, az alacsony termékenységi mutatók hozzájárultak ahhoz, hogy a háztartások átlagos mérete csökkent, így a háztartások száma megnövekedett (Champion 2001).

A természetes demográfiai folyamatokban jelentős változások történtek az elmúlt másfél évtizedben is. A kilencvenes években a természetes szaporodás mutatói erősen csökkentek az egész kontinensen, néhol negatív értékeket (természetes fogyás) értek el. Az új évezred elején ezt a tendenciát enyhe növekedés váltotta fel, ami több országban (Nyugat- és Észak-Európában) természetes népességnyereséget okozott, miközben a kontinens keleti felén jelentős természetes népességveszteséget tapasztalhatunk továbbra is.

Ha a legfrissebb statisztikai adatokat nézzük (az Eurostat adatai alapján), 2012 elején az EU-27-ek lakossága 503,7 millió fö, s ez 1,3 millió fövel volt több, mint egy évvel korábban. 2011-ben a természetes szaporodás következtében 400 ezer fővel bővült a népesség, ami a teljes növekmény 32\%-át teszi ki. A fennmaradó $68 \%$ a külső migrációnak köszönhető.

Az alábbiakban az EU-tagállamokat fő demográfiai folyamataik, s azok meghatározó oka szerint csoportosítjuk. Az Eurostat osztályozását kiegészítjük az unión kívüli, nem tagjelölt államok adataival. A csoportok a következők:

Lakosságszám-növekedés, köszönhetően

- csak a természetes változásnak: Írország, Spanyolország, Málta, Lengyelország, Izland, Macedónia;

- nagyrészt a természetes változásnak: Belgium, Franciaország, Hollandia, Szlovénia, Szlovákia, Egyesült Királyság, Törökország;

- nagyrészt a pozitív migrációs egyenlegnek: Csehország, Dánia, Ciprus, Luxemburg, Ausztria, Finnország, Svédország, Liechtenstein, Norvégia, Svájc;

- csak a pozitív migrációs egyenlegnek: Németország, Olaszország.

Lakosságszám-csökkenés, köszönhetően

- csak a természetes változásnak: Észtország, Magyarország;

- nagyrészt a természetes változásnak: Bulgária, Románia, Horvátország, Szerbia, Montenegró, Fehéroroszország, Oroszország, Ukrajna;

- nagyrészt a negatív migrációs egyenlegnek: Görögország, Lettország, Litvánia, Portugália, Bosznia-Hercegovina, Moldova;

- Csak a negatív migrációs egyenlegnek: Albánia. 


\section{A városi lakosságszám és az ország lakosságszám-változásának összevetése}

Ha koordinátarendszerben ábrázoljuk a városokban élők és a teljes lakosságszám változását az egyes országokban, akkor a négy síknegyedben világosan elkülönülő országcsoportokat figyelhetünk meg. Mivel a két mutató változása mögött demográfiai folyamatok (természetes népességszám-változás és migráció) állnak, így ezek elemzésével magyarázzuk a beállt változásokat (1. ábra).

Az első síknegyedben az a tizenhat ország szerepel, ahol a lakosságszám és a városokban élők száma egyaránt növekszik. (A vizsgált országok átlagértéke is ebben a tartományban található. Eszerint a lakosságszám 2,2\%-kal, míg a városi lakosság száma 2,9\%-kal növekedett 2001 és 2011 között Európában, tehát összességében enyhe növekedés és koncentráció jellemzi a kontinenst.) Macedónia kivételével a tizenhat ország Európa gazdaságilag jó helyzetben lévő államai, amelyek jellemzően migrációs célpontok, s természetes lakosságszám-változásuk is általában pozitív. A negyeden belül is világosan elkülöníthetők országcsoportok. Különállásukat jellemzően demográfiai mutatóik dinamikája okozza.

A koordinátarendszer második negyedében azokat az államokat találjuk, ahol az ország lakosságszámának csökkenése mellett a városi koncentrációt (a

1. ábra: Az európai országok lakosságának és a városi lakosok számának változása 2001 és 2011 között (\%)

The population change of European countries and cities between 2001 and 2011 (\%)

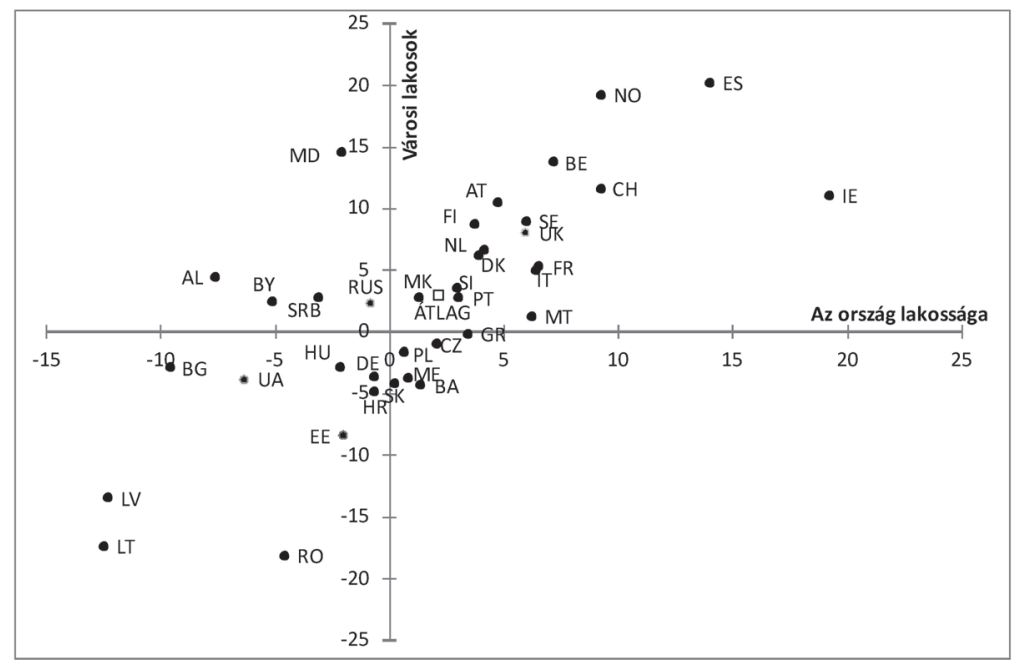

Adatok forrása: Eurostat, www.citypopulation.de és nemzeti statisztikai hivatalok. 
városi lakosok arányának növekedését) figyelhetjük meg. Az öt ország (Oroszország, Moldova, Albánia, Szerbia és Fehéroroszország) mindegyike más folyamatok révén került ebbe a kategóriába.

A koordinátarendszer harmadik negyedében található államok jelentős demográfiai problémákkal küzdenek, népességük csökken, egyúttal a városi lakosság aránya is csökken.

A negyedik síknegyedben (Lengyelország, Csehország, Szlovákia stb.) a szuburbanizáció következtében csökken a városok lélekszáma. Ehhez az össznépesség enyhe emelkedése társul, ami a pozitív, illetve javuló természetes szaporodási mutatóknak köszönhető. Ebben a negyedben kiugró értékeket nem találhatunk. Az országok az urbanizációban hasonló kategóriát képviselnek, mint Magyarország, Németország és Horvátország, de növekvő országos népességszám mellett. Tehát a városfejlődés szempontjából ezek az országok együttesen tekinthetők közép-európai kategóriának.

Mindezek alapján az alábbi városfejlődési kategóriákba sorolhatjuk a vizsgált országokat:

1. Az első, városi népességét ismét növelő országok sorába az EU-15 államainak nagy része (Németország és Görögország kivételével), valamint Svájc és Norvégia került. Adataikból látható, hogy a városi növekedést a nemzetközi vándorlási nyereség és a természetes szaporodás pozitív értékei biztosítják. Ezért ezeket az eseteket legfeljebb a „relatív koncentráció” jelzőjével foglalhatjuk össze. A viszonylag stabil gazdaságú országok fejlett térségei nyernek az Európán belüli népességmozgásból, s városi térségeik nem csupán saját országukon belül növelik arányukat, szerepüket, hanem a teljes kontinensen belül is.

2. Jól elkülöníthetőek Közép-Európa országai, amelyek a szuburbanizáció, illetve a „relatív dekoncentráció” időszakát élik. Függetlenül országuk kisebb-nagyobb mértékủ népességveszteségétől vagy -nyereségétől a belső migrációs folyamatok hajtják az urbanizációs folyamatokat, amelyek az évtized gazdasági körülményeihez igazodva erősödő, majd csökkenő szuburbanizációs folyamatban jelentkeztek.

3. A szegény vidéki térségekből a városokba irányuló belső migráció alakította a részben Kelet-Európára, részben a Balkánra jellemző csoportot, ahol az urbanizációra a „valódi koncentráció” jellemző. A második síknegyed országai mellett ide kell még sorolnunk Bulgáriát és Ukrajnát is, ahol a városi népesség aránya csökkent ugyan valamelyest, de ez a kivándorlás és a belső vándorlás egyenlegeként jöhetett létre. A belső vándorlást pedig elsősorban a nagyvárosok felé történő mozgás jellemezte.

4. Urbanizációs szempontból depressziósnak minősíthető a harmadik síknegyed három országa: Lettország, Litvánia és Románia, amelyek jelentős népességveszteség mellett a városi népesség csökkenését érték meg, $\mathrm{s}$ a belső vándorlási folyamatok sem tudták a veszteséget pótolni. Az ismert urbanizációs szakaszok egyikével sem jellemezhetjük ezeket az or- 
szágokat, hiszen a városok lélekszámának csökkenése nem írható egyértelműen a szuburbanizáció rovására.

Európában a városok fejlődésének jellemzői nem egységesen jelentkeznek, hanem az egyes nagyrégiókban eltérő folyamatokat találunk. A korábban létező különbségek elsősorban az egyes államok gazdasági fejlődési szakaszaihoz kapcsolódtak, míg mára a változást elsősorban a globalizációs tendenciák, a dinamikus nagyvárosi térségek felértékelődése és az összeurópai migrációs folyamatok alakítják. Ezeket a folyamatokat dinamizálta a 2008-ban bekövetkezett válság, amely az európai szegényebb területeket erősebben sújtotta. Így ma elmondhatjuk, hogy a szegényebb országokban a belső immigráció és a nemzetközi emigráció együttesen alakítják a városi térségek fejlődését és az országok belső területi egyensúlyának megbomlását. A kontinens fejlettebb részén egyértelműen a fejlett városi régiók növekedésének vagyunk tanúi, a gazdagabb országok többi része a dezurbanizáció fázisában található, s ez kiegyensúlyozottabb területi fejlődést jelenthet ezen országok számára.

\section{Az európai nagyvárosok fejlődésének sajátosságai, a fejlődés területi eltérései}

Az előző fejezetben láttuk, hogy a városok vitathatatlan szerepét népességszámuk folyamatos emelkedése is jelzi. Európában az 1950-es években a városi népesség aránya még alig haladta meg az 50\%-ot, 2011-ben ez az arány már 70\% felett volt, a jövőben pedig lassuló ütemben ugyan, de tovább emelkedik.

A városnövekedés mindenekelőtt nagyvárosi növekedést jelent. Ezt mutatja, hogy míg 1950-ben csak egyetlen városban élt 10 milliónál több ember a Földön, 2000-ben már 19-ben, 2013-ban pedig már 28 város lakossága haladta meg a 10 millió fós népességszámot (Enyedi 2003, 8.; http://www. citypopulation.de/world/Agglomerations.html).

A városnövekedés ugyanakkor jelentős földrajzi különbségeket is hordoz. Az 1950-es években a 15 legnagyobb népességszámú város közül 11 a fejlett országokban (6 Európában, 5 Észak-Amerikában és 1 Japánban) volt, napjainkra a legnagyobb népességü városok többsége az emelkedő, hosszabb ideje gyorsan növekvő gazdaságokhoz tartozik, és a fejlődő világ nagyvárosai is megjelennek közöttük (Enyedi 2003, 9.; http://www.citypopulation.de/world/ Agglomerations.html). Ehhez hasonló a félmilliósnál népesebb városok területi elhelyezkedése is, ezeknek mindössze 8\%-a, összesen 59 város található az EU-27 területén (Jeney 2007).

Európa városhálózatában meghatározóbbak tehát az 500 ezer fónél kisebb népességszámú városok. Ezekben a városokban és szuburbiáikban él az európai lakosság 50\%-a, míg az 500 ezresnél népesebb várok mindössze az európai lakosság 17,9\%-át adják (1. táblázat). 
Az európai városnövekedés tehát elsősorban nem nagyváros-növekedést jelent. Világviszonylatban Európában alacsony a nagyvárosok száma, bár területi elhelyezkedésük viszonylag kiegyenlített, nagyvároshiányos területekkel találkozunk a kontinens peremi területein (2. ábra).

Az EU-27 területén található 59 nagyvárosban az 1950-es években megközelítően 57 millióan éltek. A népességszám egészen az 1970-es évekig töretlenül növekedett, elérte a 68 millió főt, majd az ezredfordulóig kismértékű népességszám-csökkenés, majd lassú népességszám-emelkedés figyelhető meg (Jeney 2007). Az európai nagyvárosok fejlődésében jelentős területi különbségek rajzolódnak ki, melyek Jeney (2007) alapján az alábbiak szerint jellemezhetők az 1950 és 2007 közötti időszakban:

- 1. csoport: Főként nyugat-európai városok csoportja, a vizsgált időszak szinte egészében népességszám-csökkenés jellemző rájuk, melynek oka az elővárosok fejlődése, a szuburbanizáció és a tudatos várospolitika. Kismértékü a népességnövekedésük az 1990-es évek reurbanizációs folyamata következtében. (Pl: Amszterdam, Bécs, Berlin, Birmingham, Brüsszel, Drezda, Glasgow, Hága, Leeds, Lipcse, Lisszabon, Liverpool, London, Lyon, Manchester, Rotterdam, Sheffield.)

- 2. csoport: Főként nyugat-németországi városok csoportja, népességük növekszik az 1960-as évek végéig, de az első csoporthoz képest megkésett szuburbanizáció jellemzi őket. Az első csoporthoz hasonlóan az 1990-es évektől népességszám-emelkedés figyelhető meg körükben a reurbanizációs folyamatok következményeként. (Pl: Bréma, Dortmund, Duisburg, Düsseldorf, Essen, Frankfurt, Göteborg, Hamburg, Hannover, Helsinki, Párizs, Stockholm, Stuttgart.)

- 3. csoport: Egyedi népességnövekedési pályák jellemzik őket. (Pl: Dublin, Valencia.)

1. táblázat: Városkategóriák és a népesség megoszlása Európában

City categories and their share in Europe's population

\begin{tabular}{lcrrr}
\hline \multicolumn{1}{c}{ Kategóriák } & \multicolumn{2}{c}{ A városok száma } & \multicolumn{2}{c}{ Népesség } \\
\cline { 2 - 5 } & $d b$ & $\%$ & 154125040 & 32,1 \\
\hline Falusi népesség & & 156398720 & 32,6 \\
Kisváros, szuburbia & & & 26690068 & 5,6 \\
$50000-100000$ fó & 387 & 52,9 & 35708402 & 7,4 \\
$100000-250000$ fó & 224 & 30,6 & 21213956 & 4,4 \\
$250000-500000$ fó & 62 & 8,5 & 27041874 & 5,6 \\
$500000-1000000$ fó & 36 & 4,9 & 59292080 & 12,3 \\
$>1000000$ fő & 23 & 3,1 & 480470140 & 100,0 \\
\hline Összesen & 732 & 100,0 & & \\
\hline
\end{tabular}

Forrás: Cities of tomorrow, 2011. 
2. ábra: Nagyvároshiányos térségek az EU-27 területén

(a NUTS 3-as régiók legnépesebb településéhez való legközelebbi nagyváros távolsága, km) Metropolis deficient areas in the EU-27

(the distance of the most proximate metropolis to the most populous settlement of NUTS 3 regions, in kms)
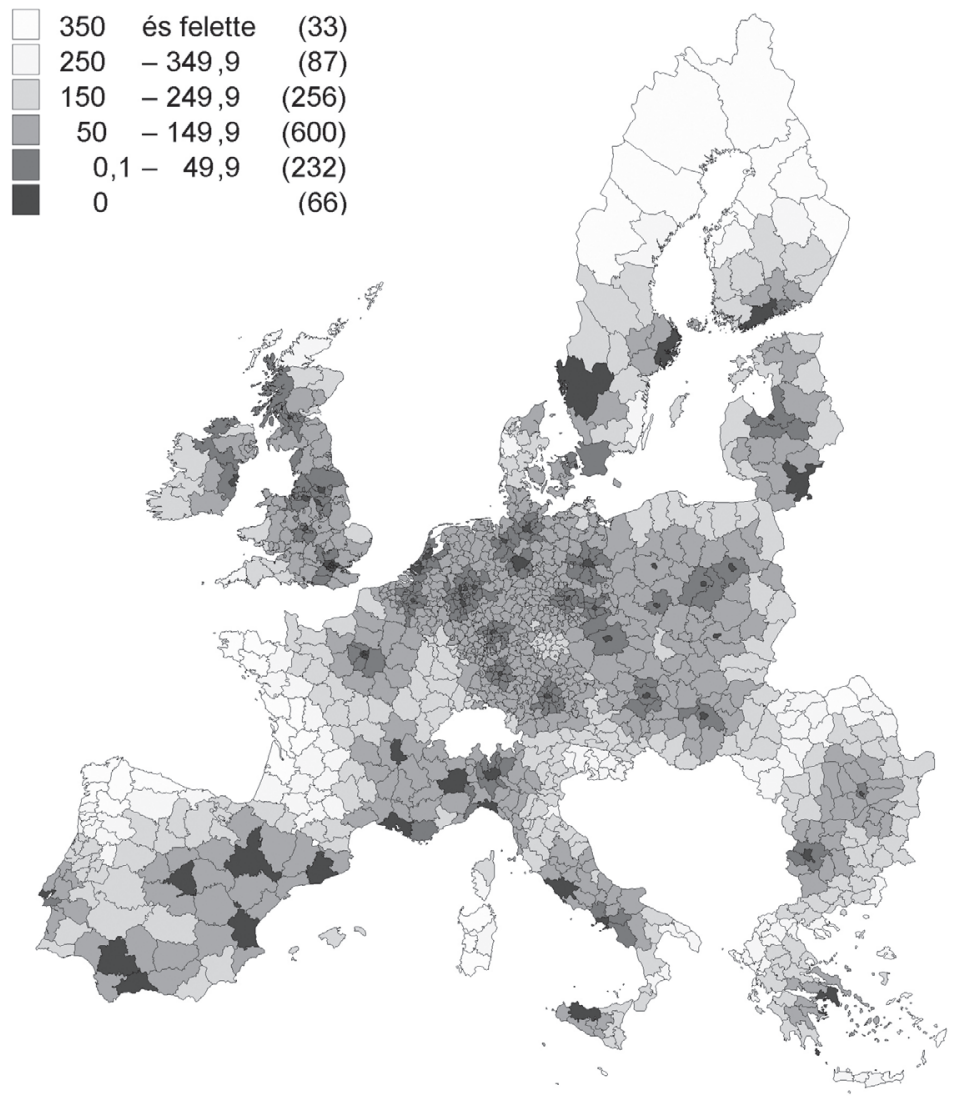

Forrás: Jeney 2007, 55.

- 4. csoport: A kelet-közép-európai növekedési pályához hasonló növekedési pályákkal, az ezredforduló után ismét népességnövekedéssel. (Pl: Szófia, Vilnius, Zaragoza.)

- 5. csoport: Főként a mediterrán városok csoportja, népességnövekedésük dinamikus az 1970-es évekig, majd az ezredforduló után ismét népességnövekedés jellemzi őket. (Pl: Athén, Barcelona, Genova, Koppenhága, Madrid, Marseille, Milánó, München, Nápoly, Róma, Torino.)

Az ESPON-kutatások igazi áttörést hoztak az európai városkutatásokban. Az ESPON 1.1.1. projekt az európai városhálózat formálódását vizsgálta 
(Potentials for... 2005). A kutatás a funkcionális várostérségek azonosítása mellett 7 tényezőcsoport (népességszám, közlekedés, idegenforgalom, ipar, tudás, döntéshozatal a magán- és közszférában) vizsgálatával kategorizálta Európa várostérségeit. A népesség legnagyobb hányada a Pentagon területén (London-Párizs-Milánó-München-Hamburg) koncentrálódik, itt megtaláljuk a milliós agglomerációkat éppúgy, mint a 250 ezer és az 1 millió lakos közötti városokat. Kelet-Közép-Európában és Dél-Olaszországban is azonosithatók azok a nagyvárosi térségek, melyek az európai városhálózat szerves részét képezik, míg Európa peremterületein, így Spanyolország déli részén, Portugáliában, továbbá Észak-Európában a nagyvárostérségek elszigetelten fejlődnek.

A vizsgálati tényezők elemzése alapján jelentős területi különbségek mutathatók ki Európában. A vizsgálat ezért arra is választ keresett, hogy Európa központi területének ellensúlyozására mely városok lehetnek alkalmasak. Ezért a MEGA (Metropolitan European Growth Area) kategóriájába került 76 várost további tényezők: „nagyság” (népességszám, gazdaság nagysága), versenyképesség (egy före jutó GDP, az 500 legnagyobb európai vállalat központjának elhelyezkedése), kapcsolatok (légi utasok száma, elérhetőség), tudásbázis (felsőfokú végzettségüek aránya, K+F-szektorban foglalkoztatottak aránya) alapján osztályozták. Az egyes kategóriákhoz tartozó városok földrajzi elhelyezkedése mutat bizonyos szabályszerűséget. A legfejlettebb városok Európa központi területein vannak, majd az egyes kategóriák (kivétel a „4. MEGA” kategória, amely elsősorban kelet-középeurópai városokat foglal magába) a legfejlettebb térségektől távolodva, övezetesen helyezkednek el, ami szintén az európai térszerkezet tagoltságára utal.

Az európai nagyvárosi fejlődés jelentősen módosítja a városok területi struktúráját. Ez elsősorban a városok területi terjeszkedését, továbbá a szűkebb térségükkel kialakított kapcsolataik változását eredményezi. Többközpontú, kevésbé hierarchizált, az infrastrukturális, gazdasági és társadalmi kapcsolatok hálózataival átszőtt urbánus térségek születnek, átértékelve mind a városok, mind pedig a vidéki térségek korábbi helyzetét. A városhálózatok létrejötte és fejlődése nagymértékben hozzájárul a policentrikus területi fejlődés megvalósulásához.

\section{Az európai várostérségek fejlettségének strukturális jellemzői}

Az elemzés célja, hogy az európai városhálózat 50-500 ezer fő közötti, közepes népességű tagjainak fejlettségbeli különbségeit elemezze az elérhető statisztikai adatok alapján. Városi adatok hiányában az elemzés a város tágabb térségére fókuszál. NUTS 3-as szintű adatokra építve a várostérségek társadalmi és gazdasági indikátorait elemezzük, és a fejlettségbeli különbségek mértéke mellett a városhálózat földrajzi tagozódásának szerkezeti jellemzőire fordítunk kiemelt figyelmet. A vizsgálat másik kulcspontja a hazai közép- és nagyvárosok várostérségi jellemzőinek pozicionálása az európai városhálózaton belül. 
Összesen 1238 db 50 ezer fönél népesebb európai városhoz rendeltünk NUTS 3 szintü térségi adatokat (az Eurostat és a www.citypopulation.de adatai alapján). A vizsgálat hatóköre harminc országra terjedt ki. Ekkora adatbázis esetében nagyon korlátozott az összehasonlítható adatok köre, a változókat az 1. melléklet tartalmazza. Városi szinten kizárólag a népességszám érhető el ilyen léptéken. A többi adat a város fölötti következő területi szintre vonatkozik. Ebből fakadóan nem a városok gazdasági és társadalmi fejlettségéről teszünk állításokat, hanem azok tágabb földrajzi környezetének fejlettségéről. Módszertani szempontból a másik fontos kérdés, hogy az adatok nem alkalmasak országos szintü összehasonlító elemzésekre, mivel nem rendelkezünk minden országból teljes körü adatmennyiséggel. Az országokra épülő osztályozás helyett egy nagyobb léptékű, földrajzi alapú (nagyrégiós) csoportosítással fogunk dolgozni. Összesen öt földrajzi egységbe rendeztük a vizsgált várostérségeket. A városok megoszlása ezek között az urbanizáltság különbségeiből fakadóan nem egyenletes. A legtöbb város a nyugati-európai zónában található (34,5\%), Közép- és Dél-Európa súlya nagyjából azonos (28\% és 24\%), míg Északés Délkelet-Európa súlya kisebb (6,3\% és 7,5\%).

Első lépésben az indikátorok leíró statisztikáit mutatjuk be (2. táblázat). A medián, a szórás és a szélsőértékek alapján az első fontos jellemző az 1181 nagyvárosi térség kiemelkedően heterogén összetétele. Az átlagos városnagyság 80000 lakos körüli. A városok többsége 10 éves távlatban, az új évezred első évtizedében növelni tudta a népességét (átlagosan 2,3\%-kal). A városok NUTS 3-as

2. táblázat: A vizsgált változók mediánértékei négy városkategóriában Medians of the tested variables in four city categories

\begin{tabular}{|c|c|c|c|c|}
\hline Változók & $\begin{array}{c}50-500 \text { ezer } \\
\text { fós városok } \\
\quad N=1181\end{array}$ & $\begin{array}{c}\text { 100-150 ezer } \\
\text { fós városok } \\
N=200\end{array}$ & $\begin{array}{c}\text { Hazai } \\
\text { nagyvárosok } \\
N=18\end{array}$ & $\begin{array}{l}\text { Györ } \\
N=1\end{array}$ \\
\hline A város népessége (fö) & 81014 & 120738 & 77067 & 131267 \\
\hline Népességszám változása 10 év alatt & $2,2 \%$ & $2,7 \%$ & $-1,2 \%$ & $1,4 \%$ \\
\hline NUTS 3 térség átlagos népessége (fö) & 530900 & 523600 & 405400 & 450900 \\
\hline Népsűrűség (fö/km²) & 266 & 241 & 87,5 & 107,0 \\
\hline Természetes népességszám-változás & $0,7 \%$ & $1,2 \%$ & $-4,7 \%$ & $-3,2 \%$ o \\
\hline Nettó migráció & $1,2 \%$ o & $1,1 \%$ o & $-0,5 \%$ o & $7,4 \%$ o \\
\hline $\begin{array}{l}\text { Fiatalkorú függőségi ráta (0-14 évesek } \\
\text { száma / 15-64 évesek száma) }\end{array}$ & $23,6 \%$ & $23,7 \%$ & $20,7 \%$ & $20,7 \%$ \\
\hline $\begin{array}{l}\text { Időskorú függőségi ráta (65-x évesek } \\
\text { száma / 15-64 évesek száma) }\end{array}$ & $26,9 \%$ & $26,5 \%$ & $24,6 \%$ & $22,8 \%$ \\
\hline $\begin{array}{l}\text { Egy fớre jutó GDP (az EU-27 átlagához } \\
\text { viszonyítva, PPS) }\end{array}$ & $96,6 \%$ & $101,3 \%$ & $46,4 \%$ & $69,4 \%$ \\
\hline Egy före jutó GDP (PPS) & 24700 & 26500 & 7100 & 11500 \\
\hline $\begin{array}{l}\text { Egy főre jutó GDP változása } 2000 \text { és } \\
\text { 2007-2010 között }\end{array}$ & $131,7 \%$ & $128,9 \%$ & $180,9 \%$ & $176,9 \%$ \\
\hline
\end{tabular}


térségei átlagosan 530 ezer főt számlálnak, magas népsűrűségi ráta mellett. Az évenkénti természetes és migrációs népességváltozás pozitív, a függőségi ráta különösen az idős korosztály esetében magas. Átlagosan 30\%-os GDP-növekedés volt megfigyelhető az évtized kezdő és záró évei között, az évtized végére számított egy före jutó GDP $25000 €$ körül van.

A Győrhöz hasonló méretű városok térségei nem különböznek jelentősen a teljes városhálózat adataitól, minden indikátor esetében a 100-150 ezer fó közötti városok NUTS 3-as szintủ térségei a teljes európai városhálózathoz nagyon hasonló értékekkel jellemezhetők. Ezzel szemben a hazai nagyvárosok és a megyei adatok jelentős eltéréseket mutatnak. A hazai nagyvárosokban az európai átlagtól eltér a népességváltozás (negatív tendencia, tízéves léptékben népességvesztés jellemző), a jóval alacsonyabb népsűrűség, a kedvezőtlen demográfiai folyamatok (népességfogyás és negatív migrációs tendenciák), illetve a nagyon kedvezőtlen GDP-adatok is szembetűnőek (a vásárlóerő-paritást figyelembe véve).

A nyugati és az északi nagytérségek régióinak demográfiai-társadalmi és gazdasági indikátorai alapvetően elkülönülnek a másik három földrajzi egység adataitól. Európa fejlettebb zónáinak adatai minden szempontból kedvezőbbek, kivéve a korszerkezetet, ami a magas összesített függőségi rátában, az egyre zsugorodó aktív korú népességben ölt testet (3. táblázat). Az eredmények megerősítik az európai térség markáns regionális különbségeit, még abban az esetben is,

3. táblázat: A fejlettségi mutatók átlagértékei nagyrégiónként, ANOVA-elemzés

(az adatok a kapcsolat erőssége, éta együttható alapján vannak rendezve) Medians of the development indicators, ANOVA analysis

(data is ordered by the strength of the association, eta coefficient)

\begin{tabular}{|c|c|c|c|c|c|c|}
\hline Változók & $\begin{array}{l}\text { Nyugat- } \\
\text { Európa }\end{array}$ & $\begin{array}{l}\text { Észak- } \\
\text { Európa }\end{array}$ & $\begin{array}{l}\text { Közép- } \\
\text { Európa }\end{array}$ & $\begin{array}{c}\text { Dél- } \\
\text { Európa }\end{array}$ & $\begin{array}{l}\text { Délkelet- } \\
\text { Európa }\end{array}$ & $\begin{array}{c}\text { éta } \\
\text { együttható }\end{array}$ \\
\hline $\begin{array}{l}\text { iatalkorú függőségi ráta (0-14 } \\
\text { évesek / 15-64 évesek) }\end{array}$ & $7,4 \%$ & $26,1 \%$ & $20,7 \%$ & $22,1 \%$ & $21,6 \%$ & 0,780 \\
\hline $\begin{array}{l}\text { NUTS } 3 \text { egy före jutó GDP-változás } \\
2000 \text { és } 2007-2010 \text { között }\end{array}$ & $114,7 \%$ & $124,9 \%$ & $137,6 \%$ & $140,7 \%$ & $224,9 \%$ & 0,663 \\
\hline Természetes népességszám-változás & $3,100 \%$ & $1,250 \%$ o & $-1,700 \%$ & $0,800 \%$ & $-2,750 \%$ & 0,635 \\
\hline Egy före jutó GDP (PPS) & 27500 & 33100 & 22850 & 21800 & 4850 & 0,485 \\
\hline $\begin{array}{l}\text { A város népességének változása } \\
10 \text { év alatt }\end{array}$ & $3,1 \%$ & $7,3 \%$ & $-1,6 \%$ & $6,6 \%$ & $-8,7 \%$ & 0,470 \\
\hline $\begin{array}{c}\text { Egy főre jutó GDP (PPS) az } \\
\text { EU27 átlagához képest }\end{array}$ & $105,7 \%$ & $105,5 \%$ & $89,4 \%$ & $95,3 \%$ & $40,2 \%$ & 0,396 \\
\hline Népsűrűség $\left(f^{\prime \prime} / \mathrm{km}^{2}\right)$ & 506,0 & 42,5 & 303,0 & 226,0 & 76,5 & 0,354 \\
\hline $\begin{array}{c}\text { Időskorú függőségi ráta (65-x } \\
\text { évesek / 15-64 évesek) }\end{array}$ & $25,8 \%$ & $29,3 \%$ & $27,5 \%$ & $27,7 \%$ & $24,0 \%$ & 0,208 \\
\hline Nettó migráció & $2,3 \%$ & $3,6 \%$ & $0,6 \%$ & $0,6 \%$ & $-0,2 \%$ o & 0,202 \\
\hline
\end{tabular}

Csak a szignifikáns csoportátlag-eltéréseket tüntettük fel. 
ha a nemzeti szint fölötti nagyobb tömbökben közelítünk az indikátorokhoz (lásd az éta asszociációs együttható értékeit).

Kétlépcsős klaszterelemzés segítségével, nyolc fejlettségi indikátor használatával osztályoztuk az 50-500 ezer fö közötti európai városok térségeit (NUTS 3-as szintü adatok). Célunk az volt, hogy az egy főre jutó GDP mellé olyan indikátorokat is be tudjunk építeni a csoportosítási folyamatba, amelyek a térségek népesedési és korszerkezeti mintázatát, trendjeit is képesek megragadni. A klaszterelemzésbe bevont változók között vagy egyáltalán nincs, vagy csak gyenge a kapcsolat $( \pm 0,1-0,2$ között mozognak a páronkénti korrelációs együtthatók). Az egyedüli kivételt - közepes mértékü korrelációs együtthatóval - a népesség növekedése, valamint a népsürüség és az egy före jutó GDP közötti pozitív összefüggés jelenti (korrelációs együtthatójuk 0,479 és 0,552).

Optimális esetben négy klaszterbe rendezhetőek a városok. A legnagyobb csoportot átlagos gazdasági fejlettség és kedvező demográfiai folyamatok jellemzik. Az aktív korosztály meghatározó súlya mellett az átlagosnál jobb fiatalkorú függőségi ráta is jellemző erre a csoportra (2. klaszter: 424 térség, 37,3\%). A második legnagyobb elemszámú csoport (4. klaszter: 335 térség, 29,4\%) szintén átlag körüli egy főre jutó GDP-vel rendelkezik, de itt alapvetően stagnáló népesség melletti elöregedési folyamat zajlik. A vizsgált térségek harmadik csoportja (3. klaszter: 246 térség, 21,6\%) az alacsony gazdasági potenciál mellett kimondottan kedvezőtlen népesedési dinamikával jellemezhető, évenkénti és 10 éves távlatban is komoly népességvesztés jellemzi ezeket a térségeket átlag alatti népsűrűség mellett (a hazai városok mindegyike ebbe a csoportba sorolható). Negyedik klaszterként sikerült kialakítani egy olyan, kisebb elemszámú városhalmazt (1. klaszter: 133 térség, 11,7\%), amely minden szempontból fejlett, növekvő és dinamikus pályán mozog, magas egy före jutó GDP-vel, méretnövekedéssel, magas népsűrüséggel. (A klaszterközéppontokat lásd a 2. mellékletben.)

Amennyiben a klasztereket és a földrajzi térségeket is rangsoroljuk, majd kereszttábla-elemzés segítségével (4. táblázat) vizsgáljuk a két csoportváltozó

4. táblázat: A fejlettségi csoportok területi megoszlása (oszlopszázalékok) Spatial sharing of the development groups (column percentages)

\begin{tabular}{l|c|c|rrr}
\hline \multirow{2}{*}{ Makrorégió } & \multicolumn{4}{c}{ Városcsoportok 8 változó alapján } & Összesen \\
\cline { 2 - 3 } & \multicolumn{1}{c}{$\begin{array}{c}\text { 1. Fejlett, } \\
\text { növekvó, sürü }\end{array}$} & $\begin{array}{c}\text { 2. Átlagos, } \\
\text { növekvo", fiatalos }\end{array}$ & $\begin{array}{c}\text { 3. Átlagos, stagnáló, } \\
\text { elöregedö }\end{array}$ & $\begin{array}{r}\text { 4. Fejletlen, } \\
\text { csökkenö, ritka }\end{array}$ \\
\hline Nyugat-Európa & $69,2 \%$ & $59,7 \%$ & $7,8 \%$ & $0,4 \%$ & $32,7 \%$ \\
Észak-Európa & $8,3 \%$ & $10,1 \%$ & $6,0 \%$ & - & $6,5 \%$ \\
Dél-Európa & $3,0 \%$ & $26,4 \%$ & $36,4 \%$ & $17,1 \%$ & $24,6 \%$ \\
Közép-Európa & $15,0 \%$ & $2,4 \%$ & $46,3 \%$ & $56,5 \%$ & $28,5 \%$ \\
Délkelet-Európa & $4,5 \%$ & $1,4 \%$ & $3,6 \%$ & $26,0 \%$ & $7,7 \%$ \\
\hline
\end{tabular}

Khi-négyzet próba: 719,2; Szignifikancia: 0,000; Cramer-féle V: 0,459. 
3. ábra: A fejlettségi csoportok területi megoszlása Spatial pattern of the development groups

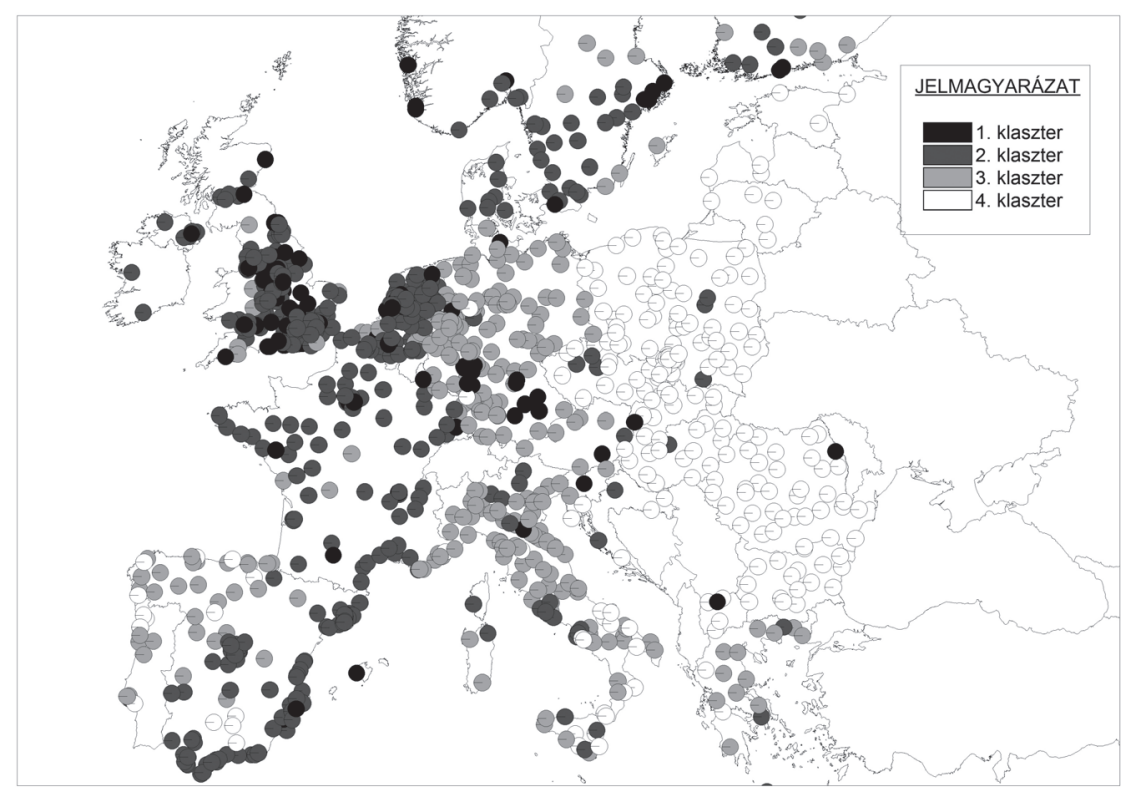

Megjegyzés: A klaszterek leírását lásd a szövegben és a 4. táblázatban.

összefüggését, akkor az ellenőrző statisztikákból egyértelműen kiderül, hogy az egyes városklaszterek területi eloszlása nem egyenletes. Egyfajta lépcsőzetes struktúrába rendeződve haladunk az északi és nyugati fekvésű fejlett klasztertől a keleti és déli fekvésű fejletlen klaszter irányába.

Összességében a klaszterek jól megragadják az európai léptékű területi egyenlőtlenségek gazdasági és demográfiai aspektusait, világosan elkülönülnek a nemzetállami keretek fölötti fejlettségi zónák (3. ábra).

\section{Jármüipari várostérségek jellemzői Európában}

Az elemzés célja feltárni, hogy a járműipari ágazat jelenléte hatással van-e, és ha igen, milyen mértékben az adott várostérség társadalmi-gazdasági mutatóira. Feltételezésünk szerint az ágazat pozitívan befolyásolja térségének gazdasági teljesítményét, és hatással lehet annak demográfiai folyamataira is. Fontos kutatási kérdés, hogy napjainkban melyek a járműgyártás által kedvelt európai országok, nagyrégiók, települési méretkategóriák. Mindezeken túl Győr városá- 
nak pozicionálása - e speciális városkörön belül - szintén a vizsgálat tárgyát képezi. A legfontosabb adatforrásokat a European Automobile Manufacturers' Association (ACEA) nemzetközi szervezet 2013. évi közlései (www.acea.be), az Eurostat, valamint a www.citypopulation.de adatbázisok jelentik. Az ACEA 2013-ban közölt adatai alapján az Európai Unió 28 tagállamában 217 olyan település található, amelyben jelen van a jármüipari ágazat. Azon településeket vizsgáltuk, ahol jelenleg motor, személygépkocsi, kis-, közepes és nagy teherautó, valamint autóbusz gyártása folyik. A vizsgálatban a makrorégiós felosztásban különválasztottuk Közép-és Kelet-Közép-Európát.

A 217 település közül mélyebb elemzésünkbe a statisztikai adatok hiánya miatt 183-at tudtunk bevonni, ez a teljes járműipari településkör több mint 84\%-a. Országos szinten a legkisebb reprezentativitással, 63,3\%-kal az Egyesült Királyság rendelkezik, hazánk esetében a vizsgálat teljes körü. Európa vezető járműipari országai Németország, Franciaország, az Egyesült Királyság és Olaszország. E négy államban található az európai járműipari települések több mint 60\%-a. A vizsgált 183 járműipari település 22,4,\%-a Közép-Európában (Németországban), 19,6\%-a Kelet-Közép-Európában, 34,9\%-a Nyugat-Európában, 18\%-a Dél-Európában, 4,9\%-a Észak-Európában, 2,1\%-a Délkelet-Európában található.

Kutatásunk alapján megállapítható, hogy a járműipari települések relatív többsége, 40,4\%-a, 74 település 50 ezer fönél alacsonyabb népességszámú. Ez elsősorban azzal magyarázható, hogy a jármügyárakat sok esetben nem egy nagyobb méretű városba, hanem annak agglomerációjába vagy fontos kikötővárosok közelébe telepítették. A legkisebb járműipari település 2011-ben 761 föt számlált. A Franciaországban található Sandouville Le Havre kikötőjétől alig 20 km-re található. Csehországban, Ostravától 28 km-re helyezkedik el a másik olyan jármüipari település, melynek lakosságszáma nem éri el az ezer főt. A legnagyobb méretű járműipari városok Köln, Prága, München, Barcelona, Bécs, Madrid és Berlin, népességszámuk 2011-ben 1 és 3,5 millió fö közötti volt. A legnagyobb mértékü népességnövekedést a jármüipari települések körében a Franciaországban található Hordain városa érte el, amely a vizsgált 10 éves ido"tartam alatt 24\%-kal (300 fővel) növelte lakosságszámát. A legnagyobb mértékben, megközelítőleg 20\%-kal Brassó, Craiova és Lovecs délkelet-európai városok veszítettek népességükből. Győr városa a 2001-es 129412 főről 2011-re 131267 före növelte népességszámát, ami 1,4\%-os emelkedést jelent. Győr városa a 100-200 ezer fó közötti népességkategóriában helyezhető el, amelyben összesen 36 európai járműipari település található.

A továbbiakban a járműipari városokra készített klaszteranalízis legfontosabb eredményeit ismertetjük. Az elemzésbe a hiányzó adatok miatt 178 település került be, amelyben viszont továbbra is hiánytalanul megtalálhatók a magyar járműipari városok. Optimális megoldásnak az 5 klaszteres elemzést találtuk, 7 változóval. Az egyes változók eltérő mértékben játszanak szerepet a klaszterek kialakításában, fontossági sorrendbe rendezhetők. A vizsgált változók a klaszterképzésben betöltött fontossági sorrendjükben a következők: 
- Népsűrűség (NUTS 3, fö/ $\mathrm{km}^{2}, 2011$ ),

- Fiatalkorú függőségi ráta (0-14 évesek /15-64 évesek) (NUTS 3, \%, 2012),

- Természetes népességszám-változás (az előző évhez képest) (NUTS 3, $\%, 2011$ ),

- Időskorú függőségi ráta (65-x évesek / 15-64 évesek) (NUTS 3, \%, 2012),

- Egy före jutó GDP (NUTS 3, €, 2007-2010),

- A város népességszáma (települési szint, fö, 2011),

- Nettó migráció (az előző évhez képest) (NUTS 3, \%, 2011).

Az első klaszter a teljes elemszám 18\%-át, a második a 9\%-át, a harmadik a 19,1\%-át, a negyedik a 35,4\%-át, az ötödik pedig a 18,5\%-át teszi ki. Az egyes klaszterek áttekinthetők aszerint, hogy az összes elemre vonatkozó átlagokhoz viszonyítva hol helyezkednek el az egyes indikátorok. Eszerint megkülönböztethetünk a klasztereken belül átlag alatti, átlagos és átlag fölötti értékekkel jellemezhető indikátorokat. Így meg tudjuk vizsgálni, melyek az átlagértékeknél előnyösebb és előnytelenebb tulajdonságai az adott klaszternek, mely klaszterek tekinthetők összességében kedvezőbb, illetve kedvezőtlenebb helyzetűnek a többi csoporthoz képest (5. táblázat).

$\mathrm{Az} 1$ 1. klaszterbe tartozó városok átlagos népessége 230 ezer fó. E városok sürün lakott NUTS 3 térségekben találhatók, a központi városban él a lakosság több mint fele. A népességszám növekedését főként a bevándorlásnak köszönhetik. E klaszterben a legkisebb mértékủ a fiatalkorú függőségi ráta, a népesség elöregedését az időskorú függőségi ráta magas szintje is alátámasztja. Ez a

5. táblázat: A klaszterek tulajdonságai a változók átlagértékeihez viszonyítva, minőségi sorrendben Features of the clusters compared to the medians of variables, in quality order

\begin{tabular}{|c|c|c|c|c|c|}
\hline \multirow[t]{2}{*}{ Változók } & \multicolumn{5}{|c|}{ Klaszterek } \\
\hline & 2. & 1. & 4. & 3. & 5. \\
\hline Népsürüség (fö/km²) (NUTS 3), 2011 & $\begin{array}{l}\text { átlag } \\
\text { fölötti }\end{array}$ & $\begin{array}{l}\text { átlag } \\
\text { fölötti }\end{array}$ & átlagos & $\begin{array}{l}\text { átlag } \\
\text { alatti }\end{array}$ & $\begin{array}{l}\text { átlag } \\
\text { alatti }\end{array}$ \\
\hline Egy főre jutó GDP $(€), 2007-2010$ & átlagos & $\begin{array}{l}\text { átlag } \\
\text { fölötti }\end{array}$ & átlagos & $\begin{array}{l}\text { átlag } \\
\text { alatti }\end{array}$ & $\begin{array}{l}\text { átlag } \\
\text { alatti }\end{array}$ \\
\hline A város népessége (fö), 2011 & $\begin{array}{l}\text { átlag } \\
\text { fölötti }\end{array}$ & $\begin{array}{l}\text { átlag } \\
\text { fölötti }\end{array}$ & átlagos & átlagos & átlagos \\
\hline $\begin{array}{l}\text { Nettó migráció (az előző évhez képest) (\%o), } \\
2011\end{array}$ & $\begin{array}{l}\text { átlag } \\
\text { fölötti }\end{array}$ & $\begin{array}{l}\text { átlag } \\
\text { fölötti }\end{array}$ & átlagos & $\begin{array}{l}\text { átlag } \\
\text { alatti }\end{array}$ & $\begin{array}{l}\text { átlag } \\
\text { alatti }\end{array}$ \\
\hline $\begin{array}{l}\text { Fiatalkorú függőségi ráta (0-14 évesek / 15-64 } \\
\text { évesek) (\%), } 2012\end{array}$ & $\begin{array}{l}\text { átlag } \\
\text { fölötti }\end{array}$ & $\begin{array}{l}\text { átlag } \\
\text { alatti }\end{array}$ & $\begin{array}{l}\text { átlag } \\
\text { fölötti }\end{array}$ & $\begin{array}{l}\text { átlag } \\
\text { alatti }\end{array}$ & $\begin{array}{l}\text { átlag } \\
\text { alatti }\end{array}$ \\
\hline $\begin{array}{l}\text { Természetes népességszám-változás (az előző } \\
\text { évhez képest) (\%), } 2011\end{array}$ & $\begin{array}{l}\text { átlag } \\
\text { fölötti }\end{array}$ & $\begin{array}{l}\text { átlag } \\
\text { alatti }\end{array}$ & $\begin{array}{l}\text { átlag } \\
\text { fölötti }\end{array}$ & $\begin{array}{l}\text { átlag } \\
\text { alatti }\end{array}$ & $\begin{array}{l}\text { átlag } \\
\text { alatti }\end{array}$ \\
\hline $\begin{array}{l}\text { Időskorú függőségi ráta (65-x évesek / 15-64 } \\
\text { évesek) (\%), } 2012\end{array}$ & $\begin{array}{l}\text { átlag } \\
\text { alatti }\end{array}$ & $\begin{array}{l}\text { átlag } \\
\text { fölötti }\end{array}$ & $\begin{array}{l}\text { átlag } \\
\text { alatti }\end{array}$ & $\begin{array}{l}\text { átlag } \\
\text { fölötti }\end{array}$ & $\begin{array}{l}\text { átlag } \\
\text { alatti }\end{array}$ \\
\hline A klaszter elemeinek száma $(\mathrm{db})$ & 16 & 32 & 63 & 34 & 33 \\
\hline
\end{tabular}


klaszter rendelkezik a legkedvezőbb gazdasági helyzettel, amit az EU-27 átlagához viszonyított egy före jutó GDP (2007-2010) magas szintje mutat.

A 2. klaszter a közel egymilliós átlagnépességű városok csoportja, gyakorlatilag nagyvárosokat és agglomerációikból álló várostérségeket jelent. A térségek népességszáma és népsürüsége rendkívül magas, ezek a nagyvárosi térségek vonzóak a migráció szempontjából, korszerkezetük harmonikus. Fontos gazdasági pólusokról van szó, amit a bruttó hazai termék átlagon felüli értéke igazol.

A 3. klaszter városainak átlagos népessége 116 ezer fö, a lakosság körülbelül egyharmada él a viszonylag kis népsűrüségü NUTS 3 térségeken belül a vizsgált városokban. 10 év alatt (2001-2011) népességszámuk állandó maradt, az időskorú népesség aránya ebben a klaszterben a legmagasabb. Gazdasági helyzetüket tekintve az átlagtól elmaradnak.

A 4. klaszter tartalmazza a legtöbb elemet és a legkisebb népességszámú városokat. E kis lakosságszámú települések a teljes NUTS 3 térség népességszámán belül átlagosan csupán 13,2\%-ot tesznek ki, tehát a 4. klaszter a legkevésbé koncentrált csoport. Ehhez a tényhez hozzájárul az is, hogy a NUTS 3 térségek népessége több mint egymillió föt számlál. A népességszám az elmúlt 10 évben átlagosan több mint 4\%-kal emelkedett. A természetes népességváltozás és a migráció mutatói pozitívak, a korszerkezet harmonikus. Gazdasági szempontból a klaszter tagjainak helyzete az összes járműipari település átlagához közeli.

$\mathrm{Az}$ 5. klaszter tagjainak átlagos népessége 114 ezer fö. A legalacsonyabb népsűrűségü NUTS 3 térségekben a vizsgált városok átlagosan 16,5\%-os arányt tesznek ki, tehát alacsonyan koncentrált területekről van szó. A 10 év alatti és az előző évhez viszonyított népességváltozás is nullához közeli negatív érték, a nettó migráció kismértékben pozitív. A fiatal- és az időskorú eltartottsági ráta néhány tizednyi eltéréssel megegyezik. A bruttó hazai termék egy főre jutó értékei mélyen az átlag alatt vannak, ezzel a vizsgált várostérségek közül a legkedvezőtlenebb gazdasági helyzetüeket foglalja magába a csoport.

Érdemes azt is áttekinteni, hogy az egyes klasztereken belül mely nagyrégió városai vannak túlsúlyban. (6. táblázat)

6. táblázat: A járműipari városok csoportjai nagyrégiók szerint (\%) Groups of automotive cities according to macroregions (\%)

\begin{tabular}{|c|c|c|c|c|c|c|c|}
\hline \multirow[t]{2}{*}{ Klaszterek } & \multicolumn{6}{|c|}{ Nagyrégiók } & \multirow[t]{2}{*}{ Összesen } \\
\hline & $\begin{array}{l}\text { Közép- } \\
\text { Európa }\end{array}$ & $\begin{array}{l}\text { Kelet-Közép- } \\
\text { Európa }\end{array}$ & $\begin{array}{l}\text { Nyugat- } \\
\text { Európa }\end{array}$ & $\begin{array}{c}\text { Dél- } \\
\text { Európa }\end{array}$ & $\begin{array}{l}\text { Észak- } \\
\text { Európa }\end{array}$ & $\begin{array}{l}\text { Délkelet- } \\
\text { Európa }\end{array}$ & \\
\hline 1. & $78,1 \%$ & $3,1 \%$ & $3,1 \%$ & $15,6 \%$ & - & - & $100,0 \%$ \\
\hline 2. & $12,5 \%$ & $25 \%$ & $43,8 \%$ & $18,8 \%$ & - & - & $100,0 \%$ \\
\hline 3. & $38,2 \%$ & $2,9 \%$ & $8,8 \%$ & $47,1 \%$ & - & $2,9 \%$ & $100,0 \%$ \\
\hline 4. & - & - & $77,8 \%$ & $7,9 \%$ & $14,3 \%$ & - & $100,0 \%$ \\
\hline 5. & - & $78,8 \%$ & - & $12,1 \%$ & - & $9,1 \%$ & $100,0 \%$ \\
\hline
\end{tabular}


A táblázat alapján elmondható, hogy a csupán Németországot magába foglaló Közép-Európa az első klaszter domináns térsége, 78,1\%-kal. A legelőnyösebb tulajdonságokkal rendelkező 2. klasztert zömében nyugat-európai (43,8\%) és kisebb mértékben (25\%) kelet-közép-európai országok járműipari városai alkotják, lengyel, cseh és osztrák elemekkel. A 3. klaszterben többségében $(47,1 \%)$ dél-európai városok találhatók, de a közép-európai Németország is képviselteti magát (38,2\%) jelentősebb arányban. A 4. klaszter egyértelműen a nyugat-európai városokat foglalja magába (77,8\%). A leggyengébb mutatókkal rendelkező 5. klaszter pedig főként a kelet-közép-európai térség településeiből áll (78,8\%), de nagyobb számban tartoznak ide Dél- és Délkelet-Európa országai közül is települések. (Lásd még a 3. mellékletet.)

Kutatási kérdésként korábban azt is megfogalmaztuk, hogy a jármüipari ágazat jelenlétének kimutatható-e valamilyen társadalmi-gazdasági hatása. A vizsgálatok alapján elmondható, hogy e városok kiemelkednek a környezetükből társadalmi-gazdasági mutatóikkal. Természetesen az, hogy kedvezőbb értékekkel rendelkeznek, nem csupán ennek az ágazatnak köszönhető. Alapvetően a jármüipari ágazat is törekszik olyan környezetben telephelyeket létesíteni, ahol egyrészt megvannak az ilyen típusú ipari hagyományok, biztosítva van a munkaerő-utánpótlás (legyen az szakképzett mérnök vagy alacsonyabb végzettségü szakmunkás), továbbá kedvezőbbek a nemzetközi és helyi jogi, gazdasági szabályozórendszerek, jó az infrastrukturális ellátottság. Ezen kívül még számtalan egyéb tényező is közrejátszik, viszont pontos számbavételük nélkül is elmondható, hogy nemcsak járműipari, hanem más ipari üzemek letelepedését is kedvezően befolyásolják. Ahol pedig ezek az ipari egységek képesek felszívni a szabad munkaerőt, beszállítóként helyi kis- és középvállalkozások tudnak csatlakozni hozzájuk, elindulhat a gazdasági fejlődés, amely sok esetben kedvező demográfiai folyamatokat képes generálni.

\section{Összegzés}

A városfejlődéssel és várostagozódással összefüggő eredményeink különböző súlypontokat kaptak annak függvényében, hogy milyen méretü városkategóriákkal foglalkoztunk. Az európai nagyvárosok esetében a demográfiai változások bizonyos urbanizációs összefüggéseit mutattuk be, mivel azok a gazdasági hatások mellett a városfejlődés szintén fontos összetevői. Négy városfejlődési kategóriát különböztettünk meg: 1 . városi népességüket ismét növelő országok (föként az EU-15 államai), ahol a városi növekedést a nemzetközi vándorlási nyereség és a természetes szaporodás pozitív értékei biztosítják. 2. Jól elkülöníthetők KözépEurópa országai, amelyek urbanizációs jellemzőiket tekintve a szuburbanizáció, illetve a „relatív dekoncentráció” időszakát élik. 3. A szegény vidéki térségekből a városokba irányuló belső migráció alakította a részben Kelet-Európára, részben a 
Balkánra jellemző csoportot, ahol az urbanizációra a „valódi koncentráció” jellemző. 4. Urbanizációs szempontból depressziósnak minősíthető speciális helyzetű országok, amelyek jelentős népességveszteség mellett a városi népesség csökkenését érték meg, a csökkenést a belső vándorlási folyamatok sem tudták pótolni.

Az európai városszerkezet strukturális jellemzői számos egyedi sajátosságot mutatnak. Az európai városnövekedés nem elsősorban a nagyvárosok növekedését jelenti. Világviszonylatban Európában kicsi a nagyvárosok száma, és bár területi elhelyezkedésük kiegyenlített, nagyvároshiányos területekkel is találkozunk a kontinens peremterületein. Az 500 ezer főnél kisebb népességű városok adják a hálózat gerincét. A nagyvárosok népességszám-változása alapján jól elkülöníthetők a nyugat-európai, a Nyugat-Európa középső részén található, a kelet-közép-európai, továbbá a dél-európai nagyvárosok. Az európai nagyvárosi fejlődés jelentősen módosítja a városok területi struktúráját is. Ez a módosulás elsősorban a városok területi terjeszkedését, továbbá szűkebb térségükkel kialakított kapcsolataik változását eredményezi.

A NUTS 3-as szintű nyilvános statisztikai adatokra építve az 50-500 ezer fő közötti közepes méretű városok és térségeik társadalmi és gazdasági indikátorait elemeztük, és a fejlettségbeli különbségek mértéke mellett a városhálózat területi, földrajzi tagozódásának szerkezeti jellemzőire fordítottunk figyelmet. Az indikátorok segítségével be tudtuk mutatni az 1181 közepes méretű város és térsége fejlettségbeli különbségeit, a városhálózat földrajzi térségek szerinti belső tagozódásának mértékét és mintázatát, valamint négy viszonylag homogén fejlettségi klaszter tulajdonságait. A fejlettségi és a területi dimenziók kombinálásával sikerült kimutatni a két adottság közti szoros összefüggést: az egyes városklaszterek területi eloszlása nem egyenletes az európai térben. Egyfajta lépcsőzetes struktúrába rendeződve haladunk az északi és nyugati fekvésü fejlett klasztertől a keleti és déli fekvésü fejletlen klaszter felé.

A járműipari vizsgálat alátámasztja a korábbi fejezetek azon megállapításait, miszerint Európa nagytérségei határozottan elkülönülnek gazdasági és társadalmi mutatóik alapján; területileg jól körülhatárolhatók a sikeres, leszakadó vagy éppen stagnáló térségek. Kelet-Közép- és Délkelet-Európában az ágazat szerepe abban rejlik, hogy kiemeli az adott várost az egyébként gyenge fejlődési folyamatokból, s némiképp jobb helyzetbe hozza őket. Nyugat-Európa területi fejlődése ettől lényegesen eltérő dimenziókban zajlik.

\section{Irodalom}

Berg, L. van den (1981): Urban Europe: Vol. 1.: Study of growth and decline. Pergamon Press, New York, Oxford

Champion, A. G. (2001): A changing demographic regime and evolving polycentric urban regions: Consequences for the size, composition and distribution of city populations. Urban Studies, 4., 657-677. 
Cheshire, P. (1995): A new phase of urban development in Western Europe? The evidence for the 1980s. Urban Studies, 7., 1045-1063.

Chorianopoulos, I. (2002): Urban restructuring and governance: North-south differences in Europe and the EU URBAN Initiative. Urban Studies, 4., 705-726.

Cities of tomorrow. Challenges, visions, ways forward. European Union, 2011. http://ec.europa.eu/regional_policy/sources/docgener/studies/pdf/citiesoftomorrow/citiesoftomorrow_final.pdf (Letöltés: 2014. január 13.)

Enyedi Gy. (1988): A városnövekedés szakaszai. Akadémiai Kiadó, Budapest

Enyedi Gy. (2003): Városi világ - városfejlődés a globalizáció korában. PTE KTK Regionális Politika és Gazdaságtan Doktori Iskola. Habilitációs előadások.

Enyedi Gy. (2012): Városi világ. Akadémiai Kiadó, Budapest

Jeney L. (2007): A nagyvárosi fejlödés sajátosságai az Európai Unió regionális folyamataiban az ezredfordulón - egységesülo" nagyvároshálózat, erősödő város-vidék ellentét. Doktori értekezés. Eötvös Loránd Tudományegyetem, Földtudományi Doktori Iskola, Budapest

Potentials for polycentric development in Europe. Espon 1.1.1. Final report. 2005. http://www.espon.eu/ export/sites/default/Documents/Projects/ESPON2006Projects/Thematic Projects/Polycentricity/fr1.1.1_revised-full.pdf (Letöltés: 2014. január 13.)

http://www.acea.be/ (Letöltés: 2013. június 20.)

http://www.citypopulation.de/world/Agglomerations.html (Letöltés: 2013. június 15.)

http://epp.eurostat.ec.europa.eu (Letöltés: 2013. június 15.)

1. melléklet: A vizsgálat leíró adatai és lehetséges függő változói Descriptive statistics and provisional dependent variables

\begin{tabular}{|c|c|c|c|}
\hline Változó kódja & Változó neve & Mértékegység & Idöpont \\
\hline \multicolumn{4}{|l|}{ Települési szint } \\
\hline VPOP2001 & A város népessége & fó & 2001 \\
\hline VPOP2011 & A város népessége & fó & 2011 \\
\hline VPOPCH01_11 & Népességszám változása 10 év alatt & $\%$ & 2001-2011 \\
\hline \multicolumn{4}{|l|}{ NUTS 3 szint } \\
\hline N3POP01 & NUTS 3 régió átlagos népessége & fó & 2001 \\
\hline N3POP08_10 & NUTS 3 régió átlagos népessége & fö & $2008-2010$ \\
\hline N3PDEN11 & Népsűrűség & fo" $/ \mathrm{km}^{2}$ & 2011 \\
\hline N3PCH11 & Népességszám-változás (előző évhez képest) & fö/1000 lakos & 2011 \\
\hline N3NPCH11 & $\begin{array}{l}\text { Természetes népességszám-változás (előző } \\
\text { évhez képest) }\end{array}$ & fö/1000 lakos & 2011 \\
\hline N3MIG11 & Nettó migráció (előző évhez képest) & fö/1000 lakos & 2011 \\
\hline N3DEP12 & $\begin{array}{l}\text { Teljes függőségi ráta (0-14+65-x évesek / 15-64 } \\
\text { évesek) }\end{array}$ & $\%$ & 2012 \\
\hline N3YOU12 & $\begin{array}{l}\text { Fiatalkorú függőségi ráta (0-14 évesek / 15-64 } \\
\text { évesek) }\end{array}$ & $\%$ & 2012 \\
\hline N3OLD12 & $\begin{array}{l}\text { Időskorú függőségi ráta ( } 65-x \text { évesek / 15-64 } \\
\text { évesek) }\end{array}$ & $\%$ & 2012 \\
\hline N3GDP00 & Egy före jutó GDP & $€$ & 2000 \\
\hline N3GDP07_10 & Egy före jutó GDP & $€$ & $2007-2010$ \\
\hline N3PPSINH09 & $\begin{array}{l}\text { Egy före jutó GDP (PPS) aránya az EU-27 } \\
\text { átlagához képest }\end{array}$ & $\%$ & 2009 \\
\hline $\mathrm{N} 3 \mathrm{GDPCH}$ & $\begin{array}{l}\text { Egy före jutó GDP változása } 2000 \text { és 2007-2010 } \\
\text { között }\end{array}$ & $\%$ & $2000-2010$ \\
\hline
\end{tabular}


2. melléklet: Az egyes klaszterek tulajdonságai, klaszterközéppontok (ANOVA elemzés) Cluster descriptions, cluster centres (ANOVA analysis)

\begin{tabular}{|c|c|c|c|c|c|}
\hline Változók & $\begin{array}{c}1 . \\
\text { Fejlett, } \\
\text { növekvö, } \\
\text { sűrü }\end{array}$ & $\begin{array}{c}2 . \\
\text { Átlagos, } \\
\text { növekvo", } \\
\text { fiatalos }\end{array}$ & $\begin{array}{c}4 . \\
\text { Átlagos } \\
\text { elöregedö }\end{array}$ & $\begin{array}{c}3 . \\
\text { Fejletlen, } \\
\text { csökkenö, } \\
\text { ritka }\end{array}$ & Összesen \\
\hline $\begin{array}{l}\text { Természetes népességszám-változás } \\
\text { (előző évhez képest), fö/1000 fö }\end{array}$ & 5,7 & 2,7 & $-2,0$ & $-1,1$ & 0,7 \\
\hline $\begin{array}{l}\text { Egy före jutó GDP változása } 2000 \text { és } \\
\text { 2007-2010 között, \% }\end{array}$ & 122,6 & 126,7 & 124,9 & 192,1 & 131,7 \\
\hline $\begin{array}{l}\text { Időskorú függőségi ráta (65-x évesek } \\
\text { / 15-64 évesek), \% }\end{array}$ & 20,6 & 26,1 & 32,5 & 22,7 & 27,0 \\
\hline $\begin{array}{l}\text { Népességszám-változás (előző évhez } \\
\text { képest), fö/1000 lakos }\end{array}$ & 10,8 & 4,8 & 0,7 & $-2,6$ & 2,6 \\
\hline $\begin{array}{c}\text { Fiatalkorú függőségi ráta (0-14 } \\
\text { évesek / 15-64 évesek), \% }\end{array}$ & 26,2 & 26,5 & 20,9 & 21,1 & 23,4 \\
\hline Egy före jutó GDP - 2007-2010 (€) & 38000 & 26600 & 27100 & 8000 & 25000 \\
\hline Egy före jutó GDP (PPS), EU-27=100\% & 140,0 & 99,6 & 103,4 & 53,6 & 96,6 \\
\hline Népsűrűség, fö/km² & 2127 & 320 & 281 & 103 & 270 \\
\hline $\begin{array}{l}\text { Teljes függőségi ráta (0-14 évesek + } \\
\text { 65-x évesek / 15-64 évesek), \% }\end{array}$ & 48,5 & 52,7 & 53,4 & 43,7 & 51,1 \\
\hline $\begin{array}{l}\text { A város népességének változása } \\
10 \text { év alatt, \% }\end{array}$ & 5,7 & 5,7 & 1,1 & $-3,7$ & 2,3 \\
\hline $\begin{array}{l}\text { Nettó migráció (előző évhez képest), } \\
\text { fö/1000 lakos }\end{array}$ & 6,8 & 1,8 & 1,9 & $-1,4$ & 1,2 \\
\hline A város népessége & 127747 & 75770 & 73581 & 94014 & 81017 \\
\hline $\begin{array}{l}\text { A NUTS } 3 \text { térség átlagos népessége, } \\
\text { ezer fö" }\end{array}$ & 850,9 & 750,7 & 312,6 & 554,0 & 530,9 \\
\hline Klaszter elemszáma & $\begin{array}{r}133 \\
(12 \%)\end{array}$ & $\begin{array}{r}424 \\
(37 \%) \\
\end{array}$ & $\begin{array}{r}335 \\
(29 \%) \\
\end{array}$ & $\begin{array}{r}246 \\
(22 \%)\end{array}$ & $\begin{array}{r}1138 \\
(100 \%)\end{array}$ \\
\hline
\end{tabular}

ANOVA elemzés, csak a szignifikáns csoportátlag-eltérések feltüntetésével. Az éta-értékek 0,308 és 0,754 között mozognak. A változókat az éta asszociációs mérőszám (a kapcsolat ereje) alapján csökkenő sorrendbe rendeztük. 
3. melléklet: A járműipari városok száma nagyrégiók és országok szerint, a klasztereken belül Automotive cities according to macroregions and countries, within clusters

\begin{tabular}{|c|c|c|c|c|c|c|}
\hline \multirow[t]{2}{*}{ Országok és nagyrégiók } & \multicolumn{5}{|c|}{ Klaszterek } & \multirow[t]{2}{*}{ Összesen } \\
\hline & 1. & 2. & 3. & 4. & 5. & \\
\hline Közép-Európa & 25 & 2 & 13 & - & - & 40 \\
\hline Németország & 25 & 2 & 13 & - & - & 40 \\
\hline Kelet-Közép-Európa & 1 & 4 & 1 & - & 26 & 32 \\
\hline Lengyelország & - & 2 & - & - & 8 & 10 \\
\hline Csehország & - & 1 & - & - & 9 & 10 \\
\hline Magyarország & - & - & - & - & 5 & 5 \\
\hline Szlovákia & - & - & - & - & 3 & 3 \\
\hline Ausztria & 1 & 1 & 1 & - & - & 3 \\
\hline Szlovénia & - & - & - & - & 1 & 1 \\
\hline Nyugat-Európa & 1 & 7 & 3 & 40 & 0 & 51 \\
\hline Egyesült Királyság & 1 & 5 & - & - & - & 6 \\
\hline Franciaország & - & 1 & 2 & 28 & - & 31 \\
\hline Belgium & - & 1 & - & 5 & - & 6 \\
\hline Hollandia & - & - & 1 & 7 & - & 8 \\
\hline Dél-Európa & 5 & 3 & 16 & 5 & 4 & 33 \\
\hline Olaszország & 5 & 1 & 7 & 3 & 1 & 17 \\
\hline Spanyolország & - & 2 & 7 & 2 & 1 & 12 \\
\hline Portugália & - & - & 2 & - & 2 & 4 \\
\hline Észak-Európa & 0 & 0 & 0 & 9 & 0 & 9 \\
\hline Finnország & - & - & - & 1 & - & 1 \\
\hline Svédország & - & - & - & 8 & - & 8 \\
\hline Délkelet-Európa & 0 & 0 & 1 & 0 & 3 & 4 \\
\hline Románia & - & - & - & - & 3 & 3 \\
\hline Bulgária & - & - & 1 & - & - & 1 \\
\hline Összesen & 32 & 16 & 34 & 63 & 33 & 178 \\
\hline
\end{tabular}

